\title{
Between Ibn Khaldun and Adam Smith (Fathers of Economics)
}

\author{
${ }^{1}$ Prof. Hamed A. Ead, ${ }^{2}$ Nada H. Eid, \\ ${ }^{I}$ Cairo University, Giza, Egypt \\ ${ }^{2}$ School of Business Administration, Ahram Canadian University, Giza Egypt
}

\begin{abstract}
Who is the father of economic sciences? If you ask this question to scholars, professors and economists; the answer you would get to be mostly or some will say Ludwig von Mises, Richard Cantillon or Carl Menger. This paper would like to highlight that both Ibn Khaldun and Adam Smith were the fathers of economics.
\end{abstract}

\section{Introduction}

Going back to history and digging into the past of the development of social science, it was found that during the $14^{\text {th }}$ Century Abd Al Rahman b. Muhammad Ibn Khaldun Al Hadrami Al Ishbili ( 1332-1406) who is known as Ibn Khaldun for short, had made great contribution in the development in economic thoughts (Bartkus,Hassan) but only was known in Arab/Islamic region, and unfortunately was not known in the west, on the other hand the west has recognized the work and contribution of Adam Smith (1723-1790) the pioneer in political economy with his well known book " An inquiry into the nature and causes of the Wealth of Nation which is shortened to "Wealth of Nation", which was published in 1776 and it was not accepted during this period and was a threat to some nations as the ideas used in this book show how should rich nations give to poor nations which led to suspending the book in certain areas at the west. Adam Smith contribution was also in economics and especially in division of labor, but he was not the first to develop in this area, as Ibn Khaldun worked on this area and other areas as theory of production, theories of value, money and prices hundred years before Adam Smith and other economic scientist.

This is not to minimize the great contribution of these Western scientist, but the fact is that Ibn Khaldun was not highlighted by any way from the west and his contribution during this era should be considered as a miracle, and adding to this he did not interfere Islam in his theories as being a Muslim scientist, especially in his book "The Maqaddimah" which was translated in later periods into English (by Franz Rosenthal).

\section{Biography}

Abd al-Rahman Ibn Mohammad Ibn Khaldun was born in Tunis in 732 A.H. (1332 C.E.) to an upper class family that had migrated from Seville in Muslim Spain. His ancestors were Yemenite Arabs who settled in Spain in the very beginning of Muslim rule in the eighth century, but after the fall of Seville, had migrated to Tunisia. He received his early education and where, still in his teens, he entered the service of the Egyptian ruler Sultan Barquq. His thirst for advanced knowledge and a better academic setting soon made him leave this service and migrate to Fez. During his formative years, Ibn Khaldun experienced his family's active participation in the intellectual life of the city, and to a lesser degree, its political life. This was followed by a long period of unrest marked by contemporary political rivalries affecting his career. The uncertainty of his career still continued, with Egypt becoming his final abode where he spent his last 24 years. Here he lived a life of fame and respect, marked by his appointment as the Chief Malakite Judge and lecturing at the AL-Azhar University, but envy caused his removal from his high judicial office as many as five times. Ibn Khaldun's chief contribution lies in philosophy of history and sociology. He sought to write a world history preamble by a first volume aimed at an analysis of historical events. This volume, commonly known as Muqaddimah or 'Prolegomena', was based on Ibn Khaldun's unique approach and original contribution and became a masterpiece in literature on philosophy of history and sociology. The chief concern of this monumental work was to identify psychological, economic, environmental and social facts that contribute to the advancement of human civilization and the currents of history. In this context, he analyzed the dynamics of group relationships and showed how group feelings, al-'Asabiyya, give rise to the ascent of a new civilization and political power and how, later on, its diffusion into a more general civilization invites the advent of a still new 'Asabiyya in its pristine form. He identified an almost rhythmic repetition of rise and fall in human civilization, and analysed factors contributing to it.

Adam Smith (1723-1790) was a Scottish moral philosopher and a pioneer of political economy. One of the key figures of the Scottish Enlightenment, Adam Smith is best known for two classic works: The Theory of Moral Sentiments (1759), and An Inquiry into the Nature and Causes of the Wealth of Nations (1776). The latter, usually abbreviated as The Wealth of Nations, is considered his magnum opus and the first modern work of economics. Smith is cited as the "father of modern economics" and is still among the most influential thinkers in 
the field of economics today. Smith studied social philosophy at the University of Glasgow and at Balliol College, Oxford, where he was one of the first students to benefit from scholarships set up by his fellow Glaswegian John Snell. After graduating, he delivered a successful series of public lectures at the University of Edinburgh, leading him to collaborate with David Hume during the Scottish Enlightenment. Smith obtained a professorship at Glasgow teaching moral philosophy, and during this time he wrote and published The Theory of Moral Sentiments. In his later life, he took a tutoring position that allowed him to travel throughout Europe, where he met other intellectual leaders of his day. Smith then returned home and spent the next ten years writing The Wealth of Nations, publishing it in 1776. He died in 1790 at the age of 67.

\section{The First Father of Economy}

Both Ibn Khaldun and Adam Smith had made contribution in the area of division of labor, where Ibn Khaldun has stressed on the importance that there should be conditions for survival, and that there is essential needs required for human survival and that individual power is not only enough to obtain these essentials (Bartkus, Hassan), adding to this in Ibn Khaldun's theory of production, he stated that individuals must work together in order to stabilize and balance their production, even in agriculture, and that a man cannot survive alone and that he needs the help of others, which would be through cooperation, the more the number of individuals working together, the more achievements they will reach (Mccaffrey).

Ibn Khaldun also has stated that there should be subdivision of jobs, and that tasks should be divided among individuals in order to reach to efficient results.

Adam Smith's contribution in regard to division of labor goes also in the same flow as Ibn Khaldun but with more details and sophistication due to the time differences between the two Scientists, where Smith has provided accounting of detailed steps of the benefits of division of labor, and that he stated that not only one person can carry out the business, and that it should be divided among workers, and he had illustrated an example about this division of labor when producing pins that " one man draws out the wire, another straight it, a third one cuts it, a forth one points it, and so on ...... and that the operation could be divided into eighteen operations ( Bartkus , Hassan as cited from Smith).

Smith added that an individual could produce no more than twenty pins per day in the absence of division of labor, while if ten employees worked together they could reach to 48,000 pins a day ( Bartkus, Hassan as cited from Smith).

Both Ibn Khaldun and Adam Smith has stated in their books the importance of production, income and the surplus of it, and most importantly the role of governments and the wealth of nations.

The West forgetting history........

Without going into details and comparison between both scientists and their contribution to the development in economics, it is worth saying that the West totally forgot the role and the contribution of Ibn Khaldun as an Arab/Islamic scientist and that relating religion to social science development, and it is not only the fault of West in forgetting the history of the contribution of Ibn Khaldun and other Arab scientist, but it is also the fault of East that may be could not believe that they could have contributed in the development of economics and creating theories that most of scholars and people are developed based on them.

The Idea is that Ibn Khaldun has made an incredible contribution in the development of economics and that he focused on different areas as the role of government, taxation, value, money ,public finance and even population in an era that its only goal was to achieve basic needs for living as food, drink, shelter.

Did modern civilization really rise from nothing, and there is no medieval time?
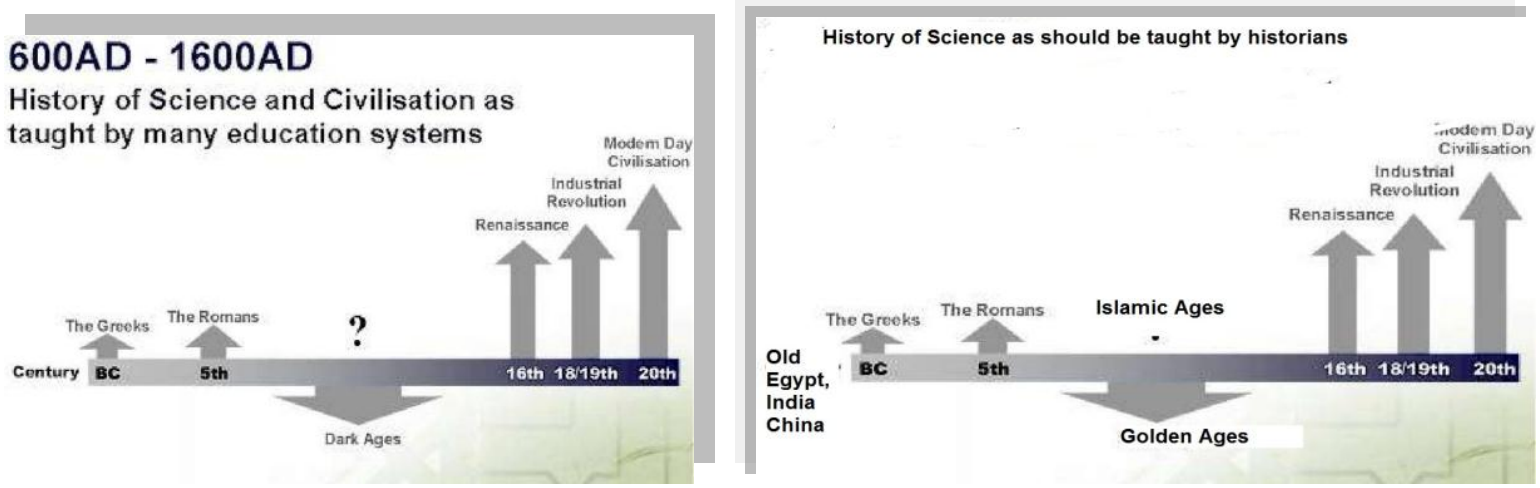

Derived from http://www.muslimheritage.com/article/one-thousand-years-missing-history/gallery/639 


\section{Conclusion}

As said by Boulakia (1971) who has provided a biography and introduced the economic ideas of Ibn Khaldun that "Ibn Khaldun has discovered the importance and the necessities of division of labor before smith, and that he already has discovered other theories before many other scientists .

It is hard to say that Ibn Khaldun is only the father of economics, as there should be a more advanced name to him and to his early contribution, and his wide thinking about different things in social science, he could be the God Father of Economics or the inspirational Father of Economics.

Finally, it is not only about the name that should be given to Ibn Khaldun or even to other unknown Arab scientist but to mention that not much contribution by Arabs were transmitted and accredited in the West, that their ideas were not to recognized due to the fear of integrating religion in their discoveries, but of course this not a rule of thumb, and that every arguments does has its exception and still some of Arab Scientists were recognized and even reached to better achievements when they were given the opportunity in the West .

\section{References}

[1] Austrian economics - Definitions, www.thedailybell.com/definitions/params/id/1918/

[2] Franz Rosenthal, lmarxistnkrumaistforum.files.wordpress.com/2013/.../the-muqaddimah.

[3] Hamed A. Ead (1998), Alchemy in Ibn Khaldun's Muqaddimah, Heidelberg University, www.levity.com/alchemy/islam.html

[4] JOE MCCAFFREY |Ibn khaldun: the forgotten father of economics? www.tcd.ie/Economics

[5] James R. Bartkus \& M. Kabir Hassan, www.uned.es/congreso-ibn-khaldun.

[6] Ali, A., Thompson, H., 1999. The Schumpeterian Gap and Muslim Economic Thought. The Journal of Interdisciplinary Economics 10, 31-49.

[7] Boulakia, J.D., 1971. Ibn Khaldun: A Fourteenth-Century Economist. Journal of Political Economy 79, 1105-1118.

[8] http://www.muslimheritage.com/article/one-thousand-years-missing-history/gallery/63

[9] Essid, M.Y., 1987. Islamic Economic Thought. In: Lowry, S.T. (ed.) Pre-Classical Economic Thought (77-146). Boston: Kluwer Academic Publishers. 